\title{
Vaccine Rejection for Parents with Babies of 0-24 Months: Solution Recommendations for Causes and Reduction
}

\author{
0-24 Aylık Bebeği Olan Ebeveynlerde Aşı Reddi: \\ Nedenleri ve Azaltılmasına Yönelik Çözüm Önerileri
}

\author{
Beyza Nur Atasever(ID), Selvinaz Sayar(ID), Mader Sabancı(ID), Ayşe Büşra Gür(ID), Hediye Karakoç(ID) \\ Department of Midwifery, Karatay University School of Health Sciences, Konya, Turkey
}

\begin{abstract}
Cite this article as: Atasever BN, Sayar S, Sabancı M, Gür AB, Karakoç H. Vaccine rejection for parents with babies of 0-24 months: Solution recommendations for causes and reduction. J Pediatr Inf 2021;15(2):e97-e102.
\end{abstract}

Abstract

Objective: The research was conducted in order to determine the mothers' attitudes towards vaccination and the reasons for vaccine rejection and to offer solutions to increase social approval.

Material and Methods: The study was conducted in two family health centers and one private hospital in Konya, between November 2019 and May 2020, with a qualitative research method in order to examine the vaccine rejection, which is considered as a global health problem, in depth. In determining the research sample, 20 mothers were interviewed by using typical case sampling, one of the purposeful sampling methods. In the study, the data were collected using the semi-structured form prepared under three main headings: "Descriptive Information Form (14 questions)" and "Opinions on Immunization", "Opinions on Vaccine Rejection" and "Opinions on the Dangers of Vaccine Rejection" developed as a result of the literature review and using an in-depth interview technique.

Results: Forty percent $(n=8)$ of the mothers are secondary school graduates, $75 \%(n=15)$ do not work, and $45 \%(n=9)$ are their first children. The average age of the children is $10.15 \pm 6.53$ months and $60 \%$ of them are male. It has been determined that mothers do not know what immunization means. Breast milk and propolis are among the traditional/alternative treatment methods used to strengthen immunity and protect against diseases, and it has been determined that herbal products and spiritual practices are included. It was determined that the majority of mothers were opposed to vaccines because of the vaccine was not produced in our country. Afterwards, it is believed that it causes autism, contains harmful substances, and the vaccinated child becomes more sick.
Öz

Giriş: Araştırma, annelerin aşı konusundaki tutumlarını ve aşı reddi nedenlerini belirleyip toplumsal onayı artırabilmek için çözüm önerileri getirebilmek amacıyla yapılmıştır.

Gereç ve Yöntemler: Çalışma küresel sağlık sorunu olarak ele alınan aşı reddini derinlemesine inceleyebilmek için nitel araştırma yöntemiyle Konya'da iki aile sağlığı merkezi ve bir özel hastanede Kasım 2019-Mayıs 2020 tarihleri arasında yapılmıştır. Araştırma örnekleminin belirlenmesinde amaçlı örneklem seçim yöntemlerinden tipik durum örneklemesi kullanılarak 20 anneyle görüşülmüştür. Araştırmada verileri “Tanıtıcı Bilgi Formu (14 soru)" ve literatür taraması sonucunda geliştirilen "Bağışıklamaya İlişkin Görüşler", "Aşı Reddine İlişkin Görüşler" ve "Aşı Reddinin Tehlikelerine İlişkin Görüşler" şeklinde üç ana başlık altında hazırlanan yarı yapılandırılmış form ile derinlemesine görüşme tekniği kullanılarak toplanmıştır.

Bulgular: Annelerin \%40 $(n=8)^{\prime}$ ' ortaokul mezunu, \%75 ( $\left.n=15\right)^{\prime}$ i çalışmamaktadır, \%45 $(n=9)$ 'inin ilk çocuğudur. Çocukların yaş ortalaması $10.15 \pm 6.53$ ay olup \%60'ı erkektir. Annelerin $(n=7)$ bağışıklamanın ne demek olduğunu bilmediği belirlenmiştir. Bağışıklığı güçlendirmek için uygulanan geleneksel/alternatif tedavi yöntemleri arasında anne sütü ve propolis ilk sıralarda yer almakta olup bitkisel ürünler ve manevi uygulamalara yer verildiği belirlenmiştir. Annelerin büyük çoğunluğunun aşıya, ülkemizde üretilmemesi nedeniyle karşıt oldukları belirlenmiştir. Sonrasında ise otizme neden olduğuna, içerisinde zararlı maddeler bulunduğuna, aşı yapılan çocuğun daha çok hastalandığına inanılmaktadır. 
Conclusion: The views that foster anti-vaccination are put forward as a claim without any scientific basis. The vaccine is a preventive public health practice whose safety has been proven over and over by evidence-based studies. For this reason, it is recommended to carry out comparative studies that reveal the difference between vaccination and non-vaccination, to increase the promotion and effectiveness of the Ministry of Health Vaccine Portal, and to know how to give consultancy to hesitant or opposing people.

Keywords: Immunization, vaccine rejection, vaccine hesitation, anti-vaccination

\section{Introduction}

Vaccination is to gain passive immunity administering weakened virus, bacteria or antigenic organisms into the body (1). Vaccination programs are the most cost-effective method to prevent and eradicate infectious diseases, to decrease morbidity and mortality of the diseases and to grow a healthy public (2-6). According to a report by the World Health Organization (WHO), global immunization prevents 2-3 million deaths annually (7). It has been verified that thanks to the immunization program carried out in our country, polio and neonatal tetanus have not occurred as of 2002 and 2009, respectively (8).

As of the 1990s in the world and 2010 in our country, notions like "vaccine hesitation-vaccine rejection" have emerged. Vaccine rejection has rapidly increased upon the winning of a lawsuit related to "obtaining consent from parents for vaccine implementations" in 2015 and anti-vaccination discourses of the media $(5,9)$.. Vaccine rejection rates in our country were 183 in 2011, 980 in 2013, 5.400 in 2015, 12.000 in 2016, and reached to 23.000 as of 2018 . As a consequence, while measles was seen in 85 children in 2017 nation-wide, the number of measles cases in the first three months of 2018 reached 44. Thus, while measles incidence was 0.01 in 100.000 population in 2016, the incidence showed a tenfold increase and increased up to 0.10 in 100.000 population (10). Should vaccine rejection cases reach 50.000, it is estimated that there will be a significant raise in the incidence of rarely seen or eradicated infectious diseases $(9,10)$.

World Health Organization included "anti-vaccination movement" in front at the top 10 global health problems to be addressed and solved in 2019 upon realizing that cases of vaccine rejection have rapidly increased in recent years and reached serious levels (11). In order to fight with vaccine rejection, it is fundamental to offer solutions in light of scientific research to be conducted on reasons of vaccine rejection and increasing community approval in vaccination practices (5). This research was planned to determine mothers' attitudes towards vaccines and their reasons to reject vaccination and to offer solutions to increase public approval.
Sonuç: Aşı karşıtlığını besleyen görüşler bilimsel bir dayanağı olmadan bir iddia olarak ortaya atılmaktadır. Aşı, güvenilirliği kanıt temelli çalışmalarla defalarca kanıtlanmış koruyucu bir halk sağlığı uygulamasıdır. Bu nedenle aşılanma ve aşılanmama durumu arasındaki farkı ortaya koyan karşılaştırmalı çalışmaların yapılması, Sağlık Bakanlığı Aşı Portalı́nın tanıtım ve etkinliğinin artırılması, sağlık çalışanlarının tereddütlü veya karşıt olan kişilere nasıl danışmanlık vermesi gerektiğini bilmesi önerilmektedir.

Anahtar Kelimeler: Bağışıklama, aşı reddi, aşı tereddütü, aşı karşıtlığı

\section{Materials and Methods}

\section{Research Type}

The research was conducted with a qualitative research method in order to thoroughly investigate the notion of vaccine rejection addressed as a global health problem.

\section{The Place and Time of Research}

The research was conducted in two family healthcare centers and one private hospital in Konya between November 2019 and May 2020.

\section{Research Population and Sample}

The research population comprised mothers who reject vaccination. In determining the research sample, typical case sampling method of the purposeful sampling selection methods was used. Research saturation in qualitative research methods is used as a term suggesting that the research can be terminated when same answers are started to be collected from the interviewees. Based upon this view and by considering that research saturation was reached, 20 mothers were interviewed.

\section{Data Collection Tools}

Data in the research were collected through "Descriptive Information Form (14 questions)" and a semi-structured form prepared under 3 main headings developed following literature review and includes Opinions on Immunization (definition of immunization), Opinions on Vaccine Rejection (reasons of not getting tetanus vaccine during pregnancy and not getting the child vaccinated), and Opinions on the Risks of Vaccine Rejection (views on the opinion that one unvaccinated child puts the health of all children at risk).

\section{Data Collection}

Data were collected using depth interview method by meeting at an appropriate day and time with the mothers who met the research inclusion criteria. The utilization of this research is referred to as method diversification. Open-ended questions provide an important flexibility in obtaining more detailed information. Even though a semi-structured interview form was used as the method of qualitative research, 
it was possible for the researcher to add new questions or change the course of the research during the interviews. Data were collected by writing and voice recorder.

\section{Data Analysis}

SPSS program was used for the analysis of quantitative data and Nvivo for qualitative data. Interview notes and voice records were transferred into written format, and 20 interview outputs were obtained. Interview records transferred into written format were studied with content analysis and interpreted by evaluating in terms of research problems. Thematic framework was determined using the answers of the participants. Quotations were made from the mothers' expressions in order to narrate their thoughts on the matter. While quoting from the mothers, coding was made from abbreviations of age and education instead of names. Coding and organizing the research data were reviewed by the researchers and an expert in his/her field.

\section{Ethics}

Prior to the commencement of the research, approvals were received from the institution and from KTO Karatay University Faculty of Medicine, Non-Pharmaceuticals and Medical Devices Research Ethics Board (dated 25.10.2019 and numbered 2019/0011). Since all research based on the participants' self-declarations are on a voluntary basis, mothers' participation had to be willingly, and it was explained that they were free to participate or not participate in the research.

\section{Limitations to the Research}

Limitation to the research is that even though the research was planned to include mothers and fathers, fathers could not participate in the research.

\section{Results}

Forty percent of the mothers $(n=8)$ were secondary school graduates, $35 \%$ were university graduates $(n=7), 25 \%$ were high school graduates $(n=5), 75 \%$ were unemployed, and $45 \%$ had their first child. Seventy-five percent of the mothers $(n=15)$ did not get their tetanus vaccination during pregnancy. Forty-five percent of the fathers were university graduates $(n=9), 30 \%$ were high school graduates $(n=6)$, and $25 \%$ were secondary school graduates $(n=5)$. Thirty percent of the participant's previous children $(n=6)$ were fully vaccinated, and $15 \%(n=3)$ were not vaccinated at all. Mean age of the children was $10.15 \pm 6.53$ months, and $60 \%$ were males. Prior to discharge from hospital, $50 \%$ of the children $(n=10)$ did not get vitamin $\mathrm{K}$ and Hepatitis $\mathrm{B}$ vaccinations. Forty-five percent of the participants $(n=9)$ indicated that friends with children at the same age recommended not getting the vaccines, 5\% $(n=1)$ said that the physician, $50 \%(n=10)$ said that the media, $10 \%(n=2)$ said that their family, and $30 \%(n=6)$ said that their spouses recommended not getting the vaccines.

\section{Views on Immunization}

"Strengthening of immunity." (P1, 40, University)

"Body system that keeps the person fit and protects from diseases." (P2, 24, University)

"I can say that it is the resistance of the body against diseases through natural or artificial means or body's defense system." (P4, 25, High school)

"I think it is something stemming from a balanced diet" (P11, 28, Secondary school)

"I do not know." (P14, 26, University)

"I think it is harmful products given to my child." (P16, 30, Secondary school)

It was established that mothers $(n=7)$ did not know what immunization means.

\section{Conventional/Alternative Treatment Modalities}

"Black seed, propolis and prayer." (K1, 40, University)

"First breastmilk until the age of 2 years. Besides this, I can prepare my baby for the future by taking B12, Omega 3, and probiotics, refraining from package goods, and eating sugar-free and natural foods." (P2, 24, University)

"Nature is the solution. Seasonal foods, tomato and pimento, vinegar, kephir, pine cone syrup, home-made molasses, hormone-free foods, yoghurt, and milk are natural means that are not artificial". (P3, 33, University)

"I use chamomile water, carob molasses, celery, honey, sage, and antibiotics. I buy propolis from herbalists. I care about hygiene." (P11, 28, Secondary school)

It was determined that breast milk and propolis were among the conventional/alternative methods practiced to be protected from diseases and boost immunity, and herbal products and spiritual practices were also included.

\section{Views on Vaccine Rejection}

"Active substances contained within, increase in autism, and the fact that vaccines are not manufactured in our country." (P1, 40, University)

"I believe that vaccines cause diseases and lead to diseases like autism. My first child got sick despite being vaccinated, that is why I am not getting my second child vaccinated." (P3, 33, University)

"I am not getting my baby vaccinated since vaccines contain monkey, fetus, chick embryo, mercury and many other harmful things and deaths increase following vaccinations." (P5, 20, High school)

"My friends who had got their children vaccinated stated that their children got sick more and they did not get their subsequent children vaccinated and these children did not 
get sick at all. Hence, I made some research on my own and read that vaccines contained substances like mercury and caused autism." (P7, 23, University)

"Many countries do not do them. Vaccines are very harmful systems for many countries. I searched many books and articles. That is why I am not getting my child vaccinated. I believe vaccines cause infertility." (P13, 24, Secondary school)

Majority of the mothers in our research were determined to be against vaccines since they were not manufactured in our country. Following that, it is believed that vaccines cause autism $(n=4)$, contained harmful substances $(n=7)$, and the child receiving the vaccines got sick more $(n=5)$.

\section{Views on the Risks of Vaccine Rejection}

"I have heard, but I do not want my child to get vaccinated with vaccines I find harmful and unsafe." (P1, 40, University)

"Yes, I have heard and read about it many times. I do not pull back by not getting my baby vaccinated. I give various supplements to strengthen his/her immunity. If immunity is strong and with God's will, each and every disease can be shaken off. Moreover, when babies are not given even water during the first 6 months of life, is it not contradictory to inject vaccines with many foreign matters?" (P2, 24, University)

"I have heard, but I do not think that this risk can be avoided by getting the vaccines, so I did not get my child vaccinated." (P9, 20, Secondary school)

"I have heard. I do not think they are deadly." (P11, 28, Secondary school)

"Thanks to vaccines, diseases such as meningitis, polio, measles, and mumps that have caused the death of many people are not lethal any more. On the other hand, data of the World Health Organization demonstrate that infection-related deaths of nearly 3 million people are prevented every year, and many diseases and epidemics are avoided." When the participants were asked to comment on this statement, it was seen that they did not trust information stating vaccines were safe and beneficial.

"Our country should put a stop to these risks by manufacturing our vaccines." (P1, 40, University)

"I disagree with this view. On the contrary, people who spoil millions of babies' intestinal microbiota with vaccines are more dangerous than unvaccinated vaccines." (P2, 24, University)

"I disagree. In our family, my first child is vaccinated and she is the one who always gets sick, infected, and has to use antibiotics. The disease not found in my unvaccinated children does not supposedly affect the vaccinated one. My daughter, despite being vaccinated, suffered from mumps and varicella, and both were severe. My unvaccinated children do not even get sick. I do not agree with this view." (P3, 33, University)
"One unvaccinated child puts the health of other children at risk". When views of the participants regarding this information was asked, all stated that they disagreed.

\section{Discussion}

Immunization is an efficient and economical method that protects the individual from diseases and disease-related risks and is carried out to increase the immunity of the individual and the public to specific infectious diseases and enable their elimination and eradication (12). In the research, it was determined that mothers lacked knowledge on what immunization is. It is considered that socio-demographic characteristics and prejudices against vaccines cause the low knowledge level on immunization. Therefore, campaigns aimed at promoting vaccines that would increase the public's interest and awareness are of vital importance to decrease vaccine rejection.

When conventional/alternative treatment modalities practiced to boost immunity and be protected from diseases were questioned, breastmilk and propolis ranked first, followed by herbal products and spiritual endeavors. An adequate and balanced nutrition is fundamental for a strong immunity. The individual's need for an adequate and balanced nutrition rises in infectious diseases, especially when high fever is present. Therefore, adequate and balanced diet is of crucial importance to strengthen the body's immune system. However, no diet or food supplement alone can prevent the transmission of an infectious disease (13).

It was determined in this research that a majority of the mothers were against vaccines since they were not manufactured in our country. Compatible with the technology of the time, varicella and rabies vaccines were manufactured in 1887 , an in 1941, 22 different vaccines were manufactured in our country. Due to the fact that our country could not keep up with the advancements in vaccine technology in later years, vaccine manufacturing activities were stopped. However, the matter of manufacturing vaccines has gained importance recently, and significant steps have been taken (14). Vaccine importation, its examination in terms of safety and suitability, and its cold chain system are carried out by the Ministry of Health. It is out of the question that imported vaccines are used without supervision and control. Moreover, there is an internet-based portal where all information regarding vaccines is shared (15). It is possible to receive correct answers to the questions in mind by forwarding them to the Ministry of Health and thus, individuals' decision on getting vaccinated will be directed.

It was also found that mothers believed that vaccines caused autism and contained harmful substances. Anti-vaccination community has grown stronger due to the fact that thiomersal containing ethyl-mercury, which is also a component of especially the measles-mumps-rubella (MMR) vaccine, has been speculated, in some studies conducted on vaccines, 
to be toxic for the central nervous system and to enable the transmission of encephalitic proteins into the blood by damaging the intestinal wall (16-18), and that autism prevalence has increased in recent years (19). When literature was reviewed, many studies have been found to not suggest an association between MMR vaccines containing thiomersal and autism (20-24). Upon the claims made, WHO stated in 2004 that thiomersal substances with mercury found in the vaccines were not at a toxic level and their use should be continued (25). Furthermore, many studies indicate that thiomersal is not a toxin but a preservative in the vaccines that prevent contamination (26-29). Second, aluminum salts that have been used for more than 70 years are now propounded to be the reason of anti-vaccination movement. "Global Advisory Committee on Vaccine Safety (GACVS)", which is one of the scientific advisory boards of the World Health Organization, published a report in 2012 and specified that there was no scientific evidence suggesting an association between aluminum-adjuvant vaccines and autism (30). Immunization calendar and vaccine studies of the Ministry of Health are wide-ranging enough to surpass many European countries. Aluminum salts in vaccines have been used since the 1930 s to boost immunity, and their dosage is very low (31).

It was found in the research that vaccinated child got sick more. Primary objective of vaccination practices is to prevent the morbidity and mortality caused by infectious diseases. Therefore, immunization is one of the most important preventive health services in improving and protecting children's health (32). As in all medical products, there may be side effects after vaccination. However, its benefits are far more than its potential side effects (9).

When the participants were asked to comment on the statement "Thanks to vaccines, diseases such as meningitis, polio, measles, and mumps that have caused the death of many people are not lethal any more. On the other hand, data of the World Health Organization demonstrate that infection-related deaths of nearly 3 million people are prevented every year, and many diseases and epidemics are avoided", it was seen that the participants did not believe in the safety and benefit of vaccines. Vaccines are the most cost-effective and reliable methods in preventing infectious diseases and protecting children's and adult's health (33). Immunization has provided the control of many infections causing epidemics such as varicella, measles, rubella, tetanus, diphtheria, and Hemophilus influenza type B. WHO states that approximately 3 million deaths are prevented every year thanks to immunization. In addition, it also has a vital role in diminishing the incidence of some cancer types, protecting from bioterrorism, preventing antibiotic resistance and decreasing costs of diagnosis and treatment (34).
When asked to comment on the statement "One unvaccinated child puts the health of other children at risk", all participants indicated that they disagreed. Immunization with vaccines is quite important to increase the level of protection from infectious diseases and create healthy generations (32). Apart from individual immunization, vaccinated individuals provide that unvaccinated individuals have a lower chance of getting in contact with the disease agent and eventually, procure that the incidence rate of the disease in the public is decreased. Moreover, vaccination contributes to the prevention of infectivity, eradication of the disease, and enables the protection of individuals that cannot be vaccinated, including immunodeficient patients, people treated for cancer, people that receive immunosuppressant treatment due to organ transplantation, and very young infants $(9,35)$. It should be essential that individuals trust health policies established to improve public health and quality of life. Vaccination is not an intervention that only concerns the individual getting vaccinated but also others living in the community, i.e., public health (31). There are many reasons to reject vaccines. It should be known that rejecting vaccination as an individual affects the public as a whole. Therefore, protection and improvement of public health must be taken into consideration, and non-scientific information must not be adopted (36).

\section{Conclusion}

Views supporting anti-vaccination are raised without any scientific basis. Vaccination is a public health practice, whose reliability has been repeatedly proven with evidence-based studies. Vaccine rejection does not only threaten the individual's health but also that of the public. In line with the research conducted, it is recommended that comparative studies that reveal the difference between vaccination and non-vaccination should be made, social studies and projects aimed at increasing public's trust to vaccines should be carried out, activities aimed at increasing awareness in vaccine campaigns (public service ads with notable people, short films regarding unvaccinated people) should be planned, publicity and effectiveness of the Ministry of Health Vaccine Portal should be increased, and the public should be encouraged to look for answers to vaccine-related questions on this portal. Furthermore, sanctions must be imposed on individuals who make news and give speeches on social media with unscientific information and cause the public to reject vaccines. Because, as emphasized before, anti-vaccination does not only put the individual's life at risk but also the health of others. Healthcare professionals must have adequate knowledge on vaccines and be aware of the fact that they have to consult individuals who are against or hesitant to vaccination. When hesitant people are approached with effective education and counseling, positive results can be obtained. 
Ethics Committe Approval: The approval for this study was obtained from KTO Karatay University Faculty of Medicine, Non-Pharmaceuticals and Medical Devices Research Ethics Board (dated 25.10.2019 and numbered 2019/0011).

Informed Consent: Patient consent was obtained.

Peer-review: Externally peer-reviewed.

Author Contributions: Concept - BNA, SS, MS, ABG, HK; Design - HK; Supervision - HK; Resource - BNA, SS, MS, ABG, HK; Data Collection and/or Processing - BNA, SS, MS, ABG, HK; Analysis and/or Interpretation - HK; Literature Search - BNA, SS, MS, ABG, HK; Writing - BNA, SS, MS, ABG, HK; Critical Review - HK.

Conflict of Interest: All authors declare that they have no conflicts of interest or funding to disclose.

Financial Disclosure: The authors declared that this study has received no financial support.

\section{References}

1. Kutlu R. Çocukluk çağı aşıları. Türkiye Klinikleri Aile Hekimliği Dergisi Özel Konular 2017;8(5):311-8. [CrossRef]

2. Argüt N, Yetim A, Gökça G. Aşı kabulünü etkileyen faktörler. Çocuk Dergisi 2016;16(1-2):16-24. [CrossRef]

3. Dubé E, Vivion M, MacDonald NE. Vaccine hesitancy, vaccine refusal and the anti-vaccine movement: Influence, impact and implications. Expert Rev Vaccines 2014;14(1):99-117. [CrossRef]

4. Fine P, Eames K, Heymann DL. "Herd immunity": A rough guide. Clin Infect Dis 2011;52(7):911-6. [CrossRef]

5. Gür E. Vaccine hesitancy-vaccine refusal. Turk Pediatr Ars 2019;54(1):12. [CrossRef]

6. Haverkate M, D'Ancona F, Giambi C, Johansen K, Lopalco PL, Cozza V, et al. Mandatory and recommended vaccination in the EU, Iceland and Norway: Results of the VENICE 2010 survey on the ways of implementing national vaccination programmes. Eurosurveillance 2012;17(22):1-6. [CrossRef]

7. World Health Organization (WHO). Immunization coverage. Available from: https://www.who.int/en/news-room/fact-sheets/detail/immunization-coverage (Accessed date: 1 August 2019). [CrossRef]

8. World Health Organization (WHO). State of the world's vaccines and immunization. $3^{\text {rd }}$ ed. Geneva. 2009. [CrossRef]

9. Bozkurt $H$. Aşı reddine genel bir bakış ve literatürün gözden geçirilmesi. Kafkas J Med Sci 2018;8(1):71-6. [CrossRef]

10. T.C. Sağlık Bakanlığı. Genişletilmiş Bağışıklama Programı Genelgesi. https://www.saglik.gov.tr/TR,11080/genisletilmis-bagisiklamaprogrami-genelgesi.html (Accessed date: 1 August 2019). [CrossRef]

11. World Health Organization (WHO). Ten threats to global health in 2019. Available from: URL: https://www.who.int/emergencies/ten-threatsto-global-health-in-2019 (Accessed date: 1 August 2019). [CrossRef]

12. American Academy of Pediatrics. Active and Passive Immunization-Prologue. In: Kimberlin DW, Brady MT, Jackson MA, Long SS, eds. Red Book: 2018 Report of the Committee on Infectious Diseases. $31^{\text {st }}$ ed. Itasca, IL: American Academy of Pediatrics. 2018:1-6. [CrossRef]

13. Food and Agriculture Organization of the Unoted Nation (FAO). Maintaining a healthy diet during the COVID-19 pandemic. March 27, 2020. Available from: http://www.fao.org/3/ca8380en/ca8380en.pdf (Accessed date: 8 July 2020). [CrossRef]

14. Babacan F. Yeni aşı üretim teknikleri. Türkiye Klin Mikrobiyoloji Enfeksiyon Derg 2002;1(1):4-16. [CrossRef]
15. Sağlık Bakanlığı. Aşı Portalı. Available from: https://asi.saglik.gov.tr/. [CrossRef]

16. Uhlmann V, Wakefield AJ, O'Leary JJ, Martin CM, Sheils O, Pilkington L, et al. Potential viral pathogenic mechanism for new variant inflammatory bowel disease. J Clin Pathol - Mol Pathol 2002;55(2):84-90. [CrossRef]

17. Bernard S, Enayati A, Redwood L, Roger H, Binstock T. Autism: A novel form of mercury poisoning. Med Hypotheses 2001;56(4):462-71. [CrossRef]

18. Bernard S, Enayati A, Roger H, Binstock T, Redwood L. The role of mercury in the pathogenesis of autism. Mol Psychiatry 2002;7:S42-3. [CrossRef]

19. Christensen D, Baio J, Braun K. Prevalence and characteristics of autism spectrum disorder among children aged 8 years-autism and developmental disabilities monitoring network, 11 Sites, United States, 2012. MMWR Surveillance Summaries 2016;65(3):1-23. [CrossRef]

20. Hornig M, Briese T, Buie T. Lack of association between measles virus vaccine and autism with Enteropathy: A Case-Control Study. PLOS ONE 2008;3(9):e3140. [CrossRef]

21. Taylor B, Miller E, Lingam R. Measles, mumps, and rubella vaccination and bowel problems or developmental regression in children with autism: population study. BMJ 2002;324(7334):393-6. [CrossRef]

22. Fombonne E, Chakrabarti S. No Evidence for a new variant of measles-mumps-rubella-Induced autism. Pediatric 2001;108(4):1-8. [CrossRef]

23. Hviit A, Stelfeld $M$, Wohlfahrt J. Association between thiomersal containing vaccine autism. JAMA 2003;290(13):1763-6. [CrossRef]

24. Dales L, Hammer SJ, Smith NJ. Time trends in autism and in MMR immunization coverage in California. J Am Med Assoc 2001;285(9):11835. [CrossRef]

25. World Health Organization (WHO). Guidelines on regulatory expectations related to the elimination, reduction or replacement of thiomersal in vaccines. WHO Tech Rep Ser 2004;926(1):95-102. [CrossRef]

26. Barile J, Kuperminc $G$, Weintraub E. Thimerosal exposure in early life and neuropsychological outcomes 7-10 years later. J Pediatr Psychol 2012;37(1):106-18. [CrossRef]

27. Thompson W, Price C, Goodson B. Vaccine Safety Datalink Team. Early thimerosal exposure and neuropsychological outcomes at 7 to 10 years. N Engl J Med 2007;357(13):1281-92. [CrossRef]

28. Stehr-Green $P$, Tull $P$, Stellfeld M. Autism and thimerosal-containing vaccines: lack of consistent evidence for an association. Am J Prev Med 2003;25(2):101-6. [CrossRef]

29. McMahon A, Iskander J, Haber P. Inactivated influenza vaccine (IIV) in children < 2 years of age: examination of selected adverse events reported to the Vaccine Adverse Event Reporting System (VAERS) after thimerosal-free or thimerosal-containing vaccine. Vaccine 2008;36(3):427-9. [CrossRef]

30. Global Advisory Committee on Vaccine Safety (GACVS): aluminium adjuvants. Weekly Epidemiol Record 2012;87(30):277-88. [CrossRef]

31. Tekinel B. Tehlikeli Olan Hangisi? Aşı mı? Aşı karşıtığı mı? Ege Tıp Bilimleri Dergisi 2020;3(2):80-2. [CrossRef]

32. Gülcü S, Arslan S. Çocuklarda aşı uygulamaları: Güncel bir gözden geçirme. Düzce Üniversitesi Sağlık Bilimleri Enstitüsü Dergisi 2018;8(1):34-43. [CrossRef]

33. Arısoy E, Çiftçi E, Hacımustafaoğlu M. Clinical practical recommendations for Turkish national vaccination schedule for previously healthy children (National Vaccination Schedule) and vaccines not included in the schedule. J Pediatr Inf 2015;9(1):1-11. [CrossRef]

34. Andre FE, Booy R, Bock HL, Clemens J, Datta SK, John TJ, et al. Vaccination greatly reduces disease, disability, death and inequity worldwide. Bulletin WHO 2008;86(1):140-6. [CrossRef]

35. Jacobson R, St. Sauver J, Finney Rutten L. Vaccine Hesitancy. Mayo Clin Proc 2015;90(11):1562-8. [CrossRef]

36. Yiğit T, Oktay BÖ, Özdemir CN, Moustafa Pasa S. Aşı karşıtlığı ve fikri gelişimi. J Soc Human Sci Res 2020;7(53):1244-61. [CrossRef] 